\title{
INFLUENCE OF PRIMING AND NITROGEN ON GROWTH BEHAVIOR OF BUCKWHEAT (Fagopyrum esculentum) IN RAINFED CONDITION OF MIDHILL IN NEPAL
}

\author{
J.J. Gairhe, T.N. Bhusal and H. Neupane \\ Institute of Agriculture and animal Sciences, Tribhuvan University, Nepal
}

\begin{abstract}
An experiment was conducted during winter, 2010/11 at IAAS, Lamjung with the objective of studying effect of seed priming and nitrogen levels on yield and yield attributing characters of buckwheat. Altogether, there were 9 treatments of seed priming hours $(0,18$ and 36) combined with nitrogen levels $(30,45$ and $60 \mathrm{~kg} / \mathrm{ha})$. The experiment was laid out in randomized complete block design and each treatment was replicated thrice. The seed priming of 36 hours had resulted in significantly higher germination percentage in both 15 days after sowing (DAS) (4.40\%) and 30 (DAS) (5.74\%) The total germination percentage was also significantly higher (48.4\%) with $36 \mathrm{hr}$ seed priming. The main and interaction effects of seed priming and nitrogen levels had significant influence on days to $50 \%$ flowering. The dry biomass per plant, grain yield, straw yield, harvest index and percentage moisture content of biomass at harvest were found nonsignificantly different due to seed priming and nitrogen levels. The highest value for dry matter accumulation per plant (5.24 gm/plant), straw yield (8706 kg/ha) and \% moisture content $(71.0 \%)$ was recorded with $36 \mathrm{hr}$ seed priming whereas the highest value for grain yield $(1599 \mathrm{~kg} / \mathrm{ha})$, and harvest index (19.8) was obtained with $18 \mathrm{hr}$ seed priming. Likewise, dry matter accumulation (5.38 gm/plant), grain yield (1575 kg/ha) and harvest index (22.0) was found highest in $45 \mathrm{~kg} \mathrm{~N} /$ ha. Similarly, the straw yield $(9153 \mathrm{~kg} / \mathrm{ha})$ and $\%$ moisture content $(75.3 \%)$ was found highest in the treatment with $60 \mathrm{~kg} \mathrm{~N} / \mathrm{ha}$. The interaction effect between nitrogen level and priming was found non-significant and the highest grain yield (2091 kg/ha) was obtained from $18 \mathrm{hr}$ seed priming with $45 \mathrm{~kg} \mathrm{~N} / \mathrm{ha}$. Phosphorus consumption rate was intrestingly higher in buckwheat plot with nitrogen application. Moderate consumption of potassium was also observed while nitrogen content in soil remain apparantly unchanged and similar was the case with soil $\mathrm{pH}$ and organic matter content. Application of phosphatic fertilizer would be benefitial for buckwheat cultivation. Further experiment should be done to verify the effective dose of fertilizer.
\end{abstract}

Key words: flowering, germination, nitrogen effect, priming

\section{INTRODUCTION}

Buckwheat (Fagopyrum esculentum), being a pseudocereal, is one of the important minor food crops in developing countries like Nepal. The crop is widely cultivated and used as a major meal in Mustang, Manang and Dopla districts. The cultivated species of buckwheat include Fagopyrum esculentum (common buckwheat) and Fagopyrum tataricum (tartary or bitter buckwheat) (Rajbhandari and Bhatta, 2008). The common buckwheat grain consists of $73 \%$ carbohydrate, $11 \%$ crude protein, $1.9 \%$ fat, $1.3 \%$ crude fiber and $1.5 \%$ ash, and valuable micronutrients like $\mathrm{B}, \mathrm{Cu}(0.01 \%), \mathrm{Mn}(0.01 \%)$, $\mathrm{Bi}(0.001 \%), \mathrm{Fe}(0.01 \%), \mathrm{Ca}(0.03 \%), \mathrm{P}(0.3 \%)$ and $\mathrm{Mg}(3 \%)$. Tartary buckwheat grain contain more than $68 \%$ carbohydrate, $13 \%$ crude protein, $2 \%$ fat, $1.5 \%$ crude fiber and 1.95 ash, Ca $(0.04 \%), \mathrm{P}$ $(0.2 \%)$ and $\mathrm{Fe}(0.01 \%)$ (Rajbhandari and Bhatta, 2008; Martin et al., 1976). It is a valuable crop plant not only from the viewpoint of its biological, medicinal and nutritional properties but also due to its suitability for low-input mountain farming as well as for commercial farming systems (Rajbhandari 
and Bhatta, 2008). Its response to fertilizer applications is less than that of other crops (White et al., 1941). The crop is likely to lodge badly in rich soils which are high in nitrogen (Sando, 1956). It will produce a better crop on infertile and poorly tilled land than other grain crops when the climate is favorable.

The agricultural sector is vulnerable to the impacts of climate change which includes increased temperature and erratic rainfall. Global climate change, in the form of rising temperature and altered soil moisture, is projected to decrease the yield of food crops over the next 50 years (Thomson et $a l ., 2005)$. For the Indian Sub-continent, it is predicted that the mean atmospheric temperature will increase by $1-4^{\circ} \mathrm{C}$ (Sinha and Sawaminathan, 1991). The production and productivity of this crop has been threatened, due to low input on one side whereas the climatic abnormality in other side. Due to heavy rain within short period of time in most part of Nepal soil fertility is declining as the heavy rain induces erosion and loss of the fertile top soil. During winter cool season when buckwheat is to be planted, field is thirsty for water. Seed priming, generally, causes faster germination and faster field emergence, which have practical agronomic implications notably under adverse germination conditions (McDonald, 2000). The crop sown in post-rainy residual soil moisture faces the problems of low germination and consequent crop stand results in low productivity. Low final harvestable plant stand is the major cause for low production and productivity. Nitrogen is thus universally limiting factor in soil and most important for crops growth and yield, its management in the field level is necessary to obtain high grain yield.

\section{MATERIALS AND METHODS}

A field experiment was conducted at IAAS-Lamjung Campus, Lamjung from November 2010 to May 2011. The area has subtropical climate and located at approximately $650 \mathrm{~m}$ above sea level. The experiment was setup in two factorial randomized complete block design (RCBD). The two factors were seed priming and nitrogen levels with 3 levels of each making nine treatments. The three levels of seed priming were 0,18 and 36 hours whereas the three levels of nitrogen were 30 , 45 and $60 \mathrm{~kg} \mathrm{~N} / \mathrm{ha}$. Each treatment was replicated thrice. The gross plot area and net plot area were 6 $\mathrm{m}^{2}\left(2 \mathrm{~m} \times 3 \mathrm{~m}\right.$ with 10 rows) and $2.4 \mathrm{~m}^{2}$ (4 rows of $3 \mathrm{~m}$ length), respectively. The planting geometry was $20 \times 5 \mathrm{~cm}$.

Treatment combination

$\mathrm{T} 1=\mathrm{S}_{1} \mathrm{~N}_{1}=0$ hour priming with $30 \mathrm{~kg} \mathrm{~N}$

$\mathrm{T} 2=\mathrm{S}_{1} \mathrm{~N}_{2}=0$ hour priming with $45 \mathrm{~kg} \mathrm{~N}$

$\mathrm{T} 3=\mathrm{S}_{1} \mathrm{~N}_{3}=0$ hour priming with $60 \mathrm{~kg} \mathrm{~N}$

$\mathrm{T} 4=\mathrm{S}_{2} \mathrm{~N}_{1}=18$ hour priming with $30 \mathrm{~kg} \mathrm{~N}$

$\mathrm{T} 5=\mathrm{S}_{2} \mathrm{~N}_{2}=18$ hour priming with $45 \mathrm{~kg} \mathrm{~N}$

T6 $=\mathrm{S}_{2} \mathrm{~N}_{3}=18$ hour priming with $60 \mathrm{~kg} \mathrm{~N}$

$\mathrm{T} 7=\mathrm{S}_{3} \mathrm{~N}_{1}=24$ hour priming with $30 \mathrm{~kg} \mathrm{~N}$

$\mathrm{T} 8=\mathrm{S}_{3} \mathrm{~N}_{2}=24$ hour priming with $45 \mathrm{~kg} \mathrm{~N}$

$\mathrm{T} 9=\mathrm{S}_{3} \mathrm{~N}_{3}=24$ hour priming with $60 \mathrm{~kg} \mathrm{~N}$

The land was prepared by ploughing with bullocks driven local plough two times followed by 3 times cross harrowing. The field leveling was accompanied with pre-sowing weeding. Well decomposed FYM@10 ton/ha was applied in the field 15 days prior to sowing.

The seed was primed, as per the hours prescribed for the particular treatment, before sowing. Seed were sown in the row with $5 \mathrm{~cm}$ depth. The $\mathrm{N}$ was applied as specified by the treatments 
while the P and K fertilizers were applied @ 30:30 kg/ha in all the treatments. The entire NPK dose was applied as basal and incorporated in the soil by loosely stirring it. Three seeds were sown in each hill, and the optimum plant population was maintained by thinning out operation when the plants were at 3-4 leaf stage. One weeding was done to remove the weeds appeared in the field. No supplemental irrigation was provided. The crops were harvested when more than $75 \%$ of the plants attained physiological maturity. The crop was spread on cemented floor for sun drying and grain was separated by using the sticks then after.

The composite soil samples were collected before planting from the plough depth of soil i.e. $15 \mathrm{~cm}$ and analysis of physicochemical properties of soil was done. After the harvesting of crops, soil samples per treatment was collected and was analyzed for studying the nutrient absorption pattern of buckwheat. Biometrical observation on plant height, number of leaves, growth analysis, yield attributing characters and phonological observations were taken from the standing crop in the experiment

\section{RESULTS AND DISCUSSION}

\section{Effect of seed priming and nitrogen dose on germination percentage}

The germination percentage was found statistically significant due to seed priming hour and nitrogen levels (Table 1). The grand mean total germination percentage observed was $38.8 \%$. The 36 $\mathrm{hr}$ seed priming had resulted significantly higher percentage (48.4\%) and it was found at par with 18 $\mathrm{hr}$ seed priming (45.6\%). The lowest germination was found in $0 \mathrm{hr}$ seed priming (22.5\%). Similarly, higher germination percentage (44.1\%) was found in $30 \mathrm{~kg} \mathrm{~N} / \mathrm{ha}$ and it was followed by $45 \mathrm{~kg} \mathrm{~N} / \mathrm{ha}$ $(40.3 \%)$ however the result was not significant. The lowest germination $(32.1 \%)$ was found at $60 \mathrm{~kg}$ N/ha.

Table 1. Total germination percentage as influenced by seed priming and nitrogen levels

\begin{tabular}{l|lll|l}
\hline \multirow{2}{*}{ Treatments } & \multicolumn{2}{|l|}{ Total germination percentage } & \multirow{2}{*}{ Mean } \\
\cline { 2 - 3 } & \multicolumn{2}{|l}{ Nitrogen dose $(\mathrm{kg} / \mathrm{ha})$} & \\
\hline Seed priming (hr) & 30 & 45 & 60 & $22.5^{\mathrm{b}}$ \\
\hline 0 & $21.8^{\mathrm{bcd}}$ & $30.8^{\mathrm{bcd}}$ & $14.9^{\mathrm{d}}$ & $45.6^{\mathrm{a}}$ \\
18 & $43.2^{\mathrm{ab}}$ & $50.9^{\mathrm{a}}$ & $42.7^{\mathrm{ab}}$ & $48.4^{\mathrm{a}}$ \\
\hline Mean & $38.8^{\mathrm{abc}}$ & $39.2^{\mathrm{abc}}$ & $38.8^{\mathrm{abc}}$ & CV $(\%)$ \\
\hline Factors & 44.1 & 40.3 & 32.1 & \\
\hline Seed priming $(\mathrm{hr})$ & 5.11 & $\mathrm{LSD}(\mathrm{p}=0.05)$ & 27.9 \\
Nitrogen levels $(\mathrm{kg} /$ & 5.11 & $10.84^{* *}$ & \\
ha) & 8.85 & $10.84^{\mathrm{NS}}$ & & \\
Interaction & $18.77^{*}$ & & \\
\hline
\end{tabular}

DAS: Days after sowing; *: Significant $(\mathrm{P}=0.05)$; **: Highly significant $(\mathrm{P}=0.01)$; ${ }^{\text {NS}}$ : Nonsignificant. Treatments means followed by common letter (s) within column are not significantly different among each other based on DMRT at $\mathrm{P}=0.05$.

Source: Field data, 2011

\section{Effect of seed priming and nitrogen dose on days to $50 \%$ flowering}

The days to $50 \%$ flowering of buckwheat was found statistically highly influenced by the seed priming and nitrogen levels (Table 2). The grand mean days required to reach in $50 \%$ flowering was 
71.6 days. Significantly longer days (83.2 days) required to achieve $50 \%$ flowering was observed in 0 $\mathrm{hr}$ seed priming. The result obtained in 18 and $36 \mathrm{hr}$ seed priming were found statistically at par (69.1 and 62.7 days respectively for 18 and $36 \mathrm{hr}$ ). Similarly, early flowering (56.3 days) was found in the field with lower dose of $\mathrm{N}$-application ( $30 \mathrm{~kg} \mathrm{~N} / \mathrm{ha}$ ). It was found statistically similar with the $45 \mathrm{~kg}$ $\mathrm{N} /$ ha (65.2 days). The $60 \mathrm{~kg} \mathrm{~N} / \mathrm{ha}$ had resulted longer time (93.4 days) to flower in buckwheat.

Table 2. Days to $50 \%$ flowering as influenced by seed priming and nitrogen levels

\begin{tabular}{|c|c|c|c|c|}
\hline \multirow{2}{*}{ Treatments } & \multicolumn{3}{|c|}{ Days to $50 \%$ flowering (DAS) } & \multirow{3}{*}{ Mean } \\
\hline & \multicolumn{3}{|c|}{ Nitrogen dose $(\mathrm{kg} / \mathrm{ha})$} & \\
\hline Seed priming (hr) & 30 & 45 & 60 & \\
\hline 0 & $62.0^{\mathrm{ab}}$ & $70.5^{\text {bc }}$ & $119.0^{\mathrm{d}}$ & $83.2^{\mathrm{a}}$ \\
\hline 18 & $62.0^{\mathrm{ab}}$ & $64.0^{\mathrm{b}}$ & $81.3^{\mathrm{c}}$ & $69.1^{\mathrm{b}}$ \\
\hline 36 & $45.0^{\mathrm{a}}$ & $61.0^{\mathrm{ab}}$ & $82.0^{\mathrm{c}}$ & $62.7^{\mathrm{b}}$ \\
\hline Mean & $56.3^{\mathrm{a}}$ & $65.2^{\mathrm{a}}$ & $93.4^{\mathrm{b}}$ & Grand mean $=71.6$ \\
\hline Factors & $\operatorname{SEM}( \pm)$ & $\operatorname{LSD}(\mathrm{p}$ & & $\mathrm{CV}(\%)$ \\
\hline \multirow{3}{*}{$\begin{array}{l}\text { Seed priming (hr) } \\
\text { Nitrogen levels } \\
\text { (kg/ha) } \\
\text { Interaction }\end{array}$} & 4.68 & $9.92 * *$ & & \multirow{3}{*}{13.9} \\
\hline & 4.68 & $9.92 * *$ & & \\
\hline & 8.11 & $17.18^{*}$ & & \\
\hline
\end{tabular}

DAS: Days after sowing; *: Significant $(\mathrm{P}=0.05)$; **: Highly significant $(\mathrm{P}=0.01)$; ${ }^{\text {NS}}$ : Nonsignificant. Treatments means followed by common letter (s) within column are not significantly different among each other based on DMRT at $\mathrm{P}=0.05$.

Source: Field data, 2011

\section{Effect of seed priming and nitrogen dose on yield of buckwheat}

The average dry matter per plant, grain \& straw yield, harvest index and percentage moisture content of buckwheat was found statistically non-significant for seed priming and nitrogen levels (Table 3). The grand average dry biomass per plant was $5.0 \mathrm{gm}$. Non-significantly highest dry biomass weight (5.24 gm) was recorded in $36 \mathrm{hr}$ seed priming followed by $0 \mathrm{hr}$ seed priming (5.09 $\mathrm{gm})$. The lowest dry biomass weight (4.67 gm) was found in $18 \mathrm{hr}$ seed priming. Similarly, the $45 \mathrm{~kg}$ $\mathrm{N} / \mathrm{ha}$ had resulted highest dry biomass weight $(5.38 \mathrm{gm})$ and it was followed by $30 \mathrm{~kg} \mathrm{~N} / \mathrm{ha}(5.0 \mathrm{gm})$ and $60 \mathrm{~kg} \mathrm{~N} / \mathrm{ha}(4.62 \mathrm{gm})$. The interaction effect of seed priming and nitrogen levels also found nonsignificantly different on dry biomass weight (Appendix 3). Non-significantly highest dry biomass ( $7.60 \mathrm{gm}$ ) was reported from $36 \mathrm{hr}$ seed priming with $45 \mathrm{~kg} \mathrm{~N} / \mathrm{ha}$ followed by $0 \mathrm{hr}$ seed priming with $30 \mathrm{~kg} \mathrm{~N} / \mathrm{ha}(6.47 \mathrm{gm})$ and $18 \mathrm{hr}$ seed priming with $60 \mathrm{~kg} \mathrm{~N} / \mathrm{ha}(5.47 \mathrm{gm})$. The lowest dry biomass weight was recorded in 36 seed priming with $60 \mathrm{~kg} \mathrm{~N} / \mathrm{ha}$ (3.87 gm).

The grand average grain yield of buckwheat was $1291 \mathrm{~kg} / \mathrm{ha}$ (Table 3). It was non-significantly higher $(1599 \mathrm{~kg} / \mathrm{ha})$ in the $18 \mathrm{hr}$ seed priming and it was followed by $36 \mathrm{hr}$ seed priming $(1243 \mathrm{~kg} /$ ha). The lowest yield (1031 kg/ha) was recorded for $0 \mathrm{hr}$ seed priming. Likewise, non-significantly highest yield (1575 kg/ha) was found in $45 \mathrm{~kg} \mathrm{~N} / \mathrm{ha}$ and then in $60 \mathrm{~kg} \mathrm{~N} / \mathrm{ha}(1275 \mathrm{~kg} / \mathrm{ha})$. The $30 \mathrm{~kg}$ $\mathrm{N} / \mathrm{ha}$ had resulted lowest yield (1042 kg/ha). When the yield was adjusted at $12 \%$ moisture content, the result was also non-significant. The highest yield in $18 \mathrm{hr}$ seed priming was supported by the lowest moisture content (Table 3). 
Table 3. Dry biomass, yield, harvest index and percentage moisture content as influenced by seed priming and nitrogen levels

\begin{tabular}{|c|c|c|c|c|c|c|}
\hline Treatments & $\begin{array}{l}\text { Dry biomass } \\
\text { (gm/plant) }\end{array}$ & $\begin{array}{l}\text { Grain yield } \\
(\mathrm{kg} / \mathrm{ha})\end{array}$ & $\begin{array}{l}\text { Adjustable grain yield } \\
(\mathrm{kg} / \mathrm{ha})(\text { at } 12 \% \mathrm{MC})\end{array}$ & $\begin{array}{l}\text { Straw yield (kg/ } \\
\text { ha) }\end{array}$ & Harvest index & $\begin{array}{l}\% \text { moisture } \\
\text { content }\end{array}$ \\
\hline \multicolumn{7}{|c|}{ Seed priming $(\mathrm{hr})$} \\
\hline 0 & 5.09 & 1031 & 975 & 6136 & 15.9 & 64.6 \\
\hline 18 & 4.67 & 1599 & 1315 & 7280 & 19.8 & 63.0 \\
\hline 36 & 5.24 & 1243 & 1081 & 8706 & 14.8 & 71.0 \\
\hline $\operatorname{LSD}(\mathrm{P}=0.05)$ & $2.748^{\mathrm{NS}}$ & $1285.2^{\mathrm{NS}}$ & $1139.2^{\mathrm{NS}}$ & $4833.5^{\mathrm{NS}}$ & $15.05^{\mathrm{NS}}$ & $14.41^{\mathrm{NS}}$ \\
\hline $\operatorname{SEM}( \pm)$ & 1.296 & 606.2 & 537.4 & 2280.1 & 7.10 & 6.8 \\
\hline \multicolumn{7}{|c|}{ Nitrogen levels (Kg/ha) } \\
\hline 30 & 5.0 & 1042 & 926 & 5219 & 17.0 & 60.3 \\
\hline 45 & 5.38 & 1575 & 1430 & 7750 & 22.0 & 62.9 \\
\hline 60 & 4.62 & 1257 & 1015 & 9153 & 11.6 & 75.3 \\
\hline $\operatorname{LSD}(p=0.05)$ & $2.748^{\mathrm{NS}}$ & $1285.2^{\mathrm{NS}}$ & $1139.2^{\mathrm{NS}}$ & $4833.5^{\mathrm{NS}}$ & $15.05 \mathrm{NS}$ & $14.41^{\mathrm{NS}}$ \\
\hline $\operatorname{SEM}( \pm)$ & 1.296 & 606.2 & 537.4 & 2280.1 & 7.10 & 6.8 \\
\hline $\mathrm{CV} \%$ & 55.0 & 99.6 & 101.5 & 65.6 & 89.3 & 21.8 \\
\hline Grand mean & 5.0 & 1291 & 1124 & 7374 & 16.9 & 66.2 \\
\hline
\end{tabular}

MC: Moisture content; ${ }^{\text {NS: }}$ Non-significant.

Source: Field data, 2011

The interaction effect of seed priming and nitrogen levels was also found non-significant for grain yield and adjustable grain yield (Figure 1). Non-significantly highest yield (2091 kg/ha) was recorded in $18 \mathrm{hr}$ seed priming with $45 \mathrm{~kg} \mathrm{~N} / \mathrm{ha}$. The next highest grain yield was found in $0 \mathrm{hr}$ seed priming with $45 \mathrm{~kg} \mathrm{~N} / \mathrm{ha}(2079 \mathrm{~kg} / \mathrm{ha}), 18 \mathrm{hr}$ seed priming with $60 \mathrm{~kg} \mathrm{~N} / \mathrm{ha}$ (1833 kg/ha), $36 \mathrm{hr}$ seed priming with $60 \mathrm{~kg} \mathrm{~N} / \mathrm{ha}(1602 \mathrm{~kg} / \mathrm{ha})$ and so on. Unlikely, the lowest yield was obtained in the $0 \mathrm{hr}$ seed priming with $60 \mathrm{~kg} \mathrm{~N} / \mathrm{ha}(335 \mathrm{~kg} / \mathrm{ha})$.

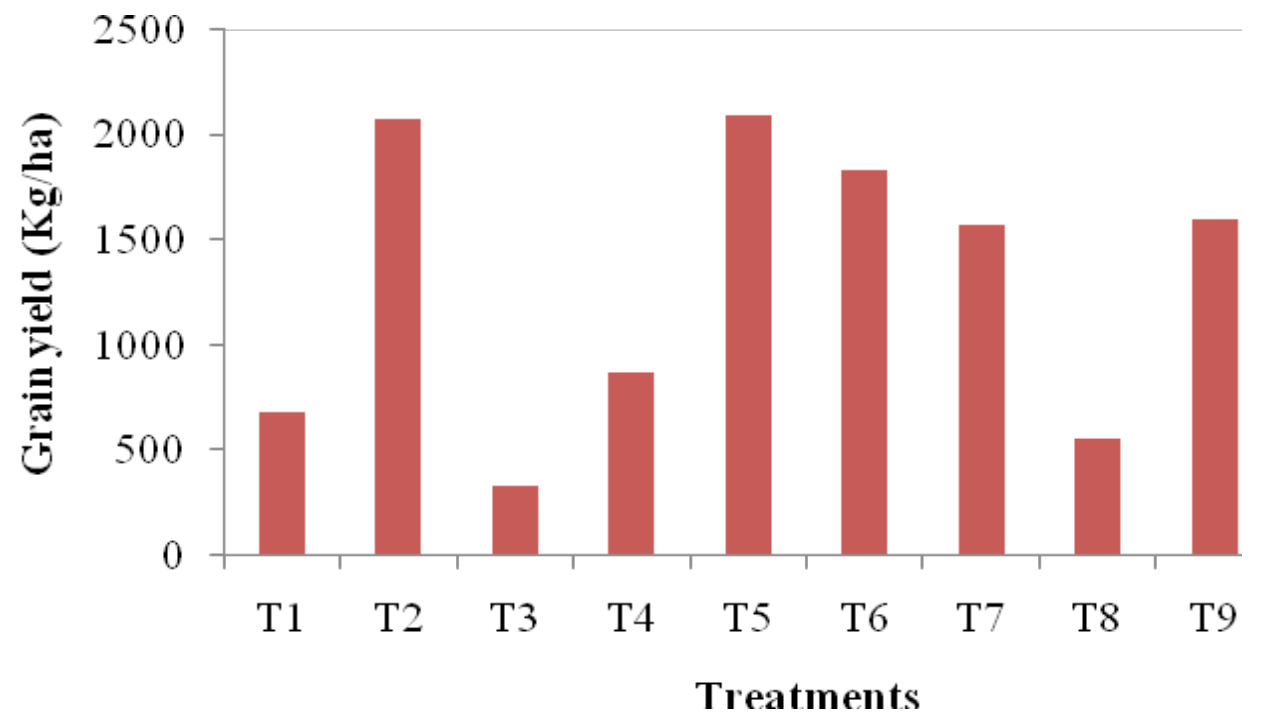

Figure 1. Grain yield of buckwheat as influenced by different treatments 
The correlation was also done for grain yield with other independent parameters (Appendix 4). The correlation of grain yield with plant population and harvest index was found significant at $P$ $=0.05$. Similalry, the values was found negative with the percetage moisture content of biomass and days to $50 \%$ flowering. Unlikely, the negative correlation was also found for dry matter accumulation at harvest. The others parameters had resulted non-significant positive correlation to grain yield. The regression analysis showed the relation between grain yield and nitrogen levels was not linear with low coefficient of determination $\left(\mathrm{R}^{2}=0.16\right)$.

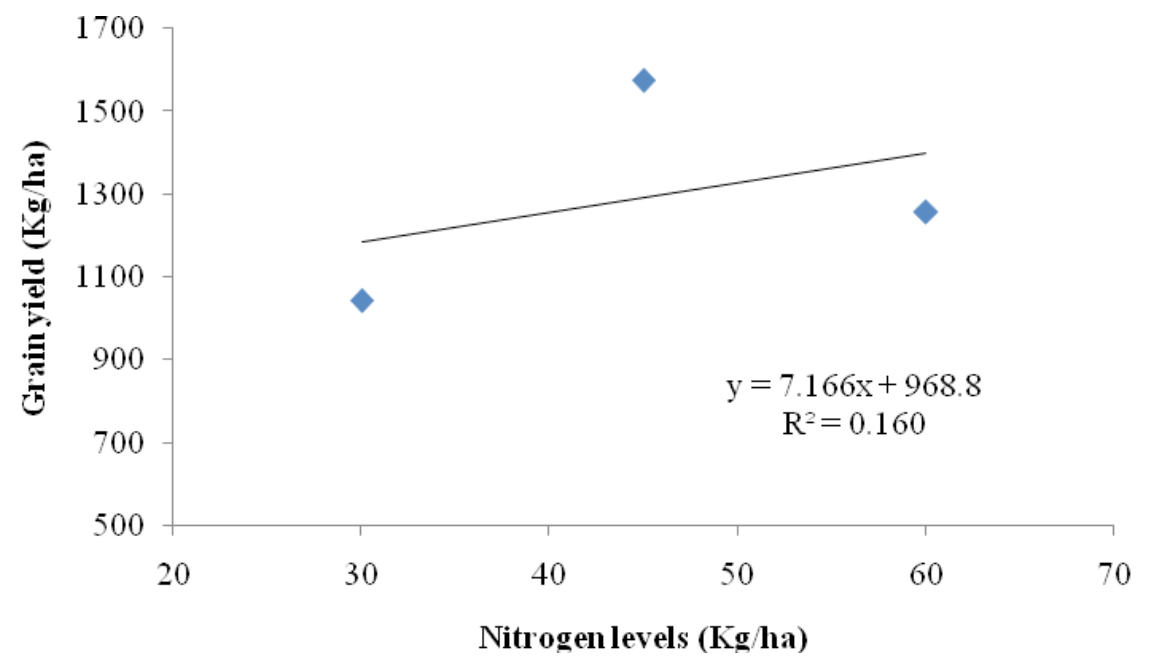

Figure 2. The regression analysis of grain yield and nitrogen levels

\section{Soil nutrient status and residual nutrient content in experimental plot}

A composite sample of soil was collected and analysed to test major nutrient status of experimental plot prior to sowing buckwheat. Soil reaction was found slightly acidic range $(5.1 \mathrm{pH})$, nitrogen content was found as $0.13 \%$ lower boundry of medium range, similarly phosphorus content was recorded as $56 \mathrm{Kg} \mathrm{P}_{2} \mathrm{O}_{5}$ per hactare was also lower range of medium range, unlike to other nutrient potassium content of the soil was found very high as $407 \mathrm{~K}_{2} \mathrm{O} \mathrm{Kg}$ per hactare.Organic matter content of the soil was in lower range of medium class as $2.6 \%$. So, buckwheat test plot was poor to medium status in major nutrient for crop production. Soil sample were again collected after crop harvesting. Treatment wise nine soil sample were tested and nutrient consumption and addition pattern was found as table 4 .

Table 4. Nutrient consumption and addition pattern in buckwheat test plot.

\begin{tabular}{lllllll}
\hline Treatment & $\mathrm{pH}$ & $\mathrm{N} \%$ & $\mathrm{P}_{2} \mathrm{O}_{5}(\mathrm{Kg} / \mathrm{ha})$ & $\mathrm{K}_{2} \mathrm{O}(\mathrm{Kg} / \mathrm{ha})$ & $\mathrm{OM} \%$ & Grain Yield $\mathrm{Kg} / \mathrm{ha})$ \\
\hline Benchmark & 5.1 & 0.13 & 56 & 407 & 2.6 & - \\
$\mathrm{T} 1$ & 5.6 & 0.13 & 0.3 & 336 & 2.5 & 680 \\
$\mathrm{~T} 2$ & 5.5 & 0.14 & 12 & 264 & 2.8 & 2079 \\
$\mathrm{~T} 3$ & 5.4 & 0.14 & 3 & 480 & 2.8 & 335 \\
$\mathrm{~T} 4$ & 5.4 & 0.11 & 3 & 264 & 2.1 & 872 \\
$\mathrm{~T} 5$ & 5.4 & 0.13 & 0.3 & 312 & 2.5 & 2091 \\
T6 & 5.5 & 0.11 & 14 & 336 & 2.5 & 1833 \\
T7 & 5.6 & 0.12 & 10 & 336 & 2.4 & 1574 \\
T8 & 5.4 & 0.13 & 10 & 408 & 2.5 & 554 \\
T9 & 5.3 & 0.11 & 31 & 336 & 2.3 & 1602 \\
\hline
\end{tabular}

Source: Lab Analysis, 2011 
Observing overall nutrient use pattern was not so convincing as treatment and yield of buckwheat. However, phosphorus consumption rate was intrestinigly higher in buckwheat plot with nitrogent application. Moderate consumption of potassium was also observed while nitrogen content in soil remain apparantly unchange and similar case for soil reaction and organic matter content (Table 4). Therefore, application of phosphatic fertilizer would be benefitial for buckwheat cultivation. Plant sample should be analysed to verify the nutrient consumption ratio. Further experiment should be carried out to recommend the effective dose of fertilizer.

\section{CONCLUSION}

Buckwheat is an important winter season crop for hilly areas but is cultivated in rainfed marginal lands and has low productivity. There is need to increase its yield through better cultivation practices with scientific know how. To obtain higher yield under rainfed conditions, the crop needs priming with water for $18 \mathrm{hr}$ and manage the nitrogen at the rate of $30-45 \mathrm{~kg} / \mathrm{ha}$. Excess nitrogen causes lower grain yield even though the biomass yield is higher. Phosphorus consumption rate was intrestingly higher in buckwheat plot with nitrogen application. Moderate consumption of potassium was also observed while nitrogen content in soil remain apparantly unchange and similar case for soil reaction and organic matter content. Application of phosphatic fertilizer would be benefitial for buckwheat cultivation. Further experiment should be done to verify the effective dose of fertilizer.

\section{ACKNOWLEDGEMENTS}

The authors are grateful to Research Division, Tribhuvan University, Kirtipur, Kathmandu(Mini Research Award (2068/069) and Institute of Agriculture and Animal Science, Lamjung Campus for providing financial and managerial supports, respectively. Special thanks go to the students who were involved in the experiment who are highly acknowledged for their cooperat ion.

\section{REFERENCES CITED}

Martin, J.H., W.H. Leonard and D.L. Stamp. 1976. Principles of field crop production. USA: Macmillan Publishing Co.

McDonald, M.B. 2000. Seed priming, in Black M \& J.D. Bewley (eds) Seed technology and its biologival basis. Sheffield, UK: Sheffield Academic Press Ltd. pp 287-325.

Rajbhandari, B.P. \& G.D. Bhatta. 2008. Food crops: agro ecology and modern agro techniques. Kathmandu: Himalayan College of Agricultural Sciences and Technology.

Sando, W.J. 1956. Buckwheat culture. USDA Farmers Bul. 2095.

Sinha, S.K. \& M.S. Swaminathan. 1991. Deforestation, climate change and sustainable nutrition security: a case study of India. Climate change. Vol- 19. pp 201-209. 
Thomson, A.M., R.A. Brown, N.J. Rosenberg, R.C. Izaurralde and V. Benson. 2005. Climate change impacts for the conterminous USA: an integrated assessment. Part 3. Dryland production of grain and forage crops. Climate Change. Vol- 69. pp 43-65.

White, J.W., F.J. Holben and A.C. Richer. 1941. Experiments with buckwheat. Pa. Agr. Exp. Sta. Bul. p 403. 